\title{
Optimising Residential Water Heating System Performance to Minimise Water-energy Penalties
}

\author{
Abel Silva Vieira', Sarah Humphrys ${ }^{2}$, Cara D. Beal ${ }^{* 3}$, Rodney A. Stewart ${ }^{4}$ \\ ${ }^{1}$ School of Engineering, Griffith University, Southport, QLD4222, Australia \\ e-mail: sv.abel@gmail.com \\ ${ }^{2}$ School of Engineering, Griffith University, Southport, QLD4222, Australia \\ e-mail: sarah.humphrys@ griffithuni.edu.au \\ ${ }^{3}$ Smart Water Research Centre and School of Engineering, Griffith University, Southport, QLD 4222, \\ Australia \\ e-mail: c.beal@ griffith.edu.au \\ ${ }^{4}$ School of Engineering, Griffith University, Southport, QLD4222, Australia \\ e-mail: r.stewart@griffith.edu.au
}

Cite as: Vieira, A. S., Humphrys, S., Beal, C. D., Stewart, R. A., Optimising Residential Water Heating System Performance to Minimise Water-energy Penalties, J. sustain. dev. energy water environ. syst., 4(2), pp 161-172, 2016, DOI: http://dx.doi.org/10.13044/j.sdewes.2016.04.0013

\begin{abstract}
The energy consumption associated with domestic hot water supply services correspond to a significant portion of the total energy consumption of the urban water cycle. The objective of this study is to analyse the performance of domestic water heaters in the three largest cities of Australia (i.e. Sydney, Melbourne and Brisbane). The performance of systems was investigated undertaking a multi-parametric analysis, in which energy efficiency indicators (i.e. energy intensity and power peaks) were combined with level of service indicators (i.e. compliance rate with minimum temperature thresholds for end use points and hot water tanks). The operation of water heaters was modelled using the software EnergyPlus. Results demonstrate the need for a more holistic approach for the design and assessment of domestic water heaters taking into account not only the technology type to heat water, but also site specific aspects.
\end{abstract}

\section{KEYWORDS}

Domestic water heaters, Hot water tank size, Electricity supply tariffs, Hot water consumption pattern, Energy efficiency, Australia.

\section{INTRODUCTION}

Buildings are responsible for approximately $50 \%$ of the national energy consumption of several countries [1], for which a considerable amount is used to supply the residential sector. On average, $16 \%$ of the total energy consumption worldwide is related to residential buildings. This proportion tends to increase in developed countries. For example, in the USA and the UK, the residential sector accounts for $22 \%$ and $28 \%$ of the total national energy consumption, respectively [2].

Hot water service is among the largest residential energy end uses, accounting for $17 \%$ in the USA [2], $20 \%$ in Brazil [3] and 22\% in the UK [2] of the total energy consumption. Additionally, hot water services make up for more than $90 \%$ of the total energy consumption of the urban water cycle, i.e. from water supply to treated wastewater disposal [4]. As a consequence, environmental impacts of the urban water cycle are intricately connected to the energy consumption of water heating systems [5].

\footnotetext{
${ }^{*}$ Corresponding author
} 
In this context, previous researchers have identified that the reduction of domestic hot water consumption patterns can markedly influence the overall water and energy demand in cities [6]. Therefore, managing the domestic hot water demand, particularly during peak hours for the electricity grid, is a key initiative to achieve citywide energy efficiency objectives [7]. Also, key demand management strategies for peak load reduction typically focus on the use of renewable energy technologies (e.g. solar), energy efficient systems (e.g. heat pumps) and implementation of variable tariff structures (e.g. peak and off-peak).

In Australia, new electricity supply tariff structures are targeted at reducing residential peak energy consumption, whereby electricity utilities have introduced off-peak, shoulder and controlled load tariff options for Domestic Water Heaters (DWHs). In combination with off-peak tariff incentives, rebate programs have also been introduced to encourage the uptake of energy efficient DWHs in Australia. For instance, the Renewable Energy Bonus Scheme was introduced throughout Australia in 2007 to recompense customers who would replace existing electric DWHs with solar or heat pump systems. In South-east Queensland (SEQ) alone, over AUD 90 million was allocated to household rebate programs [8].

Despite the implementation of rebate programs for energy efficient DWHs (i.e. solar and heat pump water heaters), the energy performance of such technologies is dependent upon their ability to reduce both the total and the peak energy consumption at adequate hot water service temperatures under varied weather conditions, hot water usage patterns and electricity supply tariffs [9]. For example, the selection of electricity supply tariffs (e.g. all-day, controlled off-peak, night rate off-peak) plays a significant role in the performance of hot water systems, as the supply of electricity at off-peak hours may not suit the demand patterns of a particular household, and, hence, reduce the compliance rate of DWH with minimum temperature thresholds for hot water services. Thus, depending on the system design and demand patterns, the capacity and efficiency to deliver adequate volumes of hot water may be constrained or sub-optimal to varying extents.

The lack of knowledge and uncertainties related to the performance of DWHs may jeopardise the implementation of relevant building code requirements aimed at promoting long-term energy efficient hot water services in new developments. Further, there is a dearth of studies that compare the performance of varied types of water heaters taking into consideration different operational indictors.

The present study seeks to narrow this knowledge gap by analysing the performance of DWHs in Sydney, Melbourne and Brisbane taking into account different water consumption patterns, hot water tank capacities and electricity supply tariffs. The performance of hot water systems was investigated undertaking a multi-parametric analysis, in which energy efficiency indicators (i.e. energy intensity and power peaks) were combined with level of service indicators (i.e. compliance rate with minimum temperature thresholds for end use points and hot water tanks) in a holistic approach.

\section{METHOD}

\section{Overview}

Three domestic water heating systems were analysis considering the local conditions of the three largest Australian cities, namely Brisbane (sub-tropical climate), Sydney (mild temperate climate) and Melbourne (cool temperate climate) located along the East coast of Australia. For each system type and city weather condition combination, twelve scenarios were assessed taking into account two water consumption patterns (100 and 
210 litres per household per day [L/hh/day]), two hot water tank capacities (160 and 330 L), and three electricity supply tariffs (all day, controlled, and night off-peak). Simulations were carried out using EnergyPlus v8.1 energy simulation software, which is an open access software for energy analysis that is provided by the United States Department of Energy. Figure 1 shows an overview of the method.

\section{Objective}

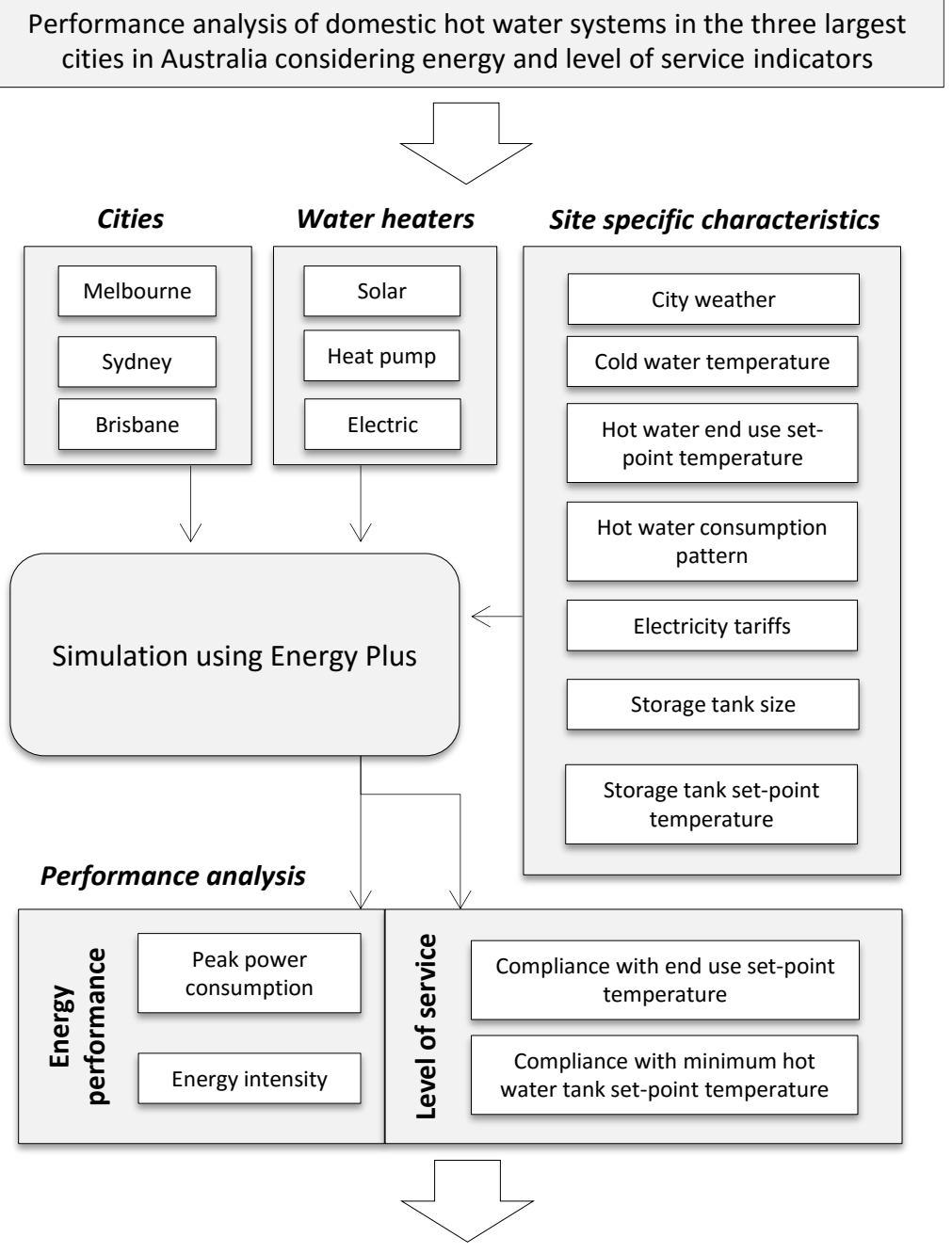

Key performance parameters identification

Outline the driving factors which influence the performance of water heating systems in residential buildings in the three largest cities in Australia

Figure 1. Method overview

\section{Assumptions and input data}

Time step and weather file. The study encompassed an annual analysis of the performance of water heating systems (i.e. analysis for all days of the year). The simulations were carried out considering a time step equal to one hour. The weather conditions for the three assessed cities was based on Representative Meteorological Year (RMY) climate files from the weather station located at Sydney (WMO 947680), Melbourne (WMO 948680) and the Brisbane Airport (WMO 945780). These files were downloaded from the EnergyPlus website. 
Temperature. Cold water temperatures were derived from air temperature by using the method described by Hendron et al. [10]. The hot water temperature set-point for end uses $\left(40^{\circ} \mathrm{C}\right)$ was approximately equal to the one described by Kenway [11], and the low and upper temperature thresholds for hot water tanks $\left(60-70{ }^{\circ} \mathrm{C}\right)$ was considered to be within the range suggested by the Plumbing Reference Guide of Australia [12].

Electricity supply tariffs. Three electricity supply tariffs were analysed:

- A standard tariff with 24 hours electricity supply;

- A controlled tariff with 18 hours supply from 12 AM to 7 AM, 9 AM to 4 PM and $9 \mathrm{PM}$ to $12 \mathrm{AM}$;

- A nigh off-peak supply with 8 hours supply from 12 AM to 7 AM and 11 PM to 12 AM.

Each tariff represent different levels of intermittence of electricity supply to water heating systems, which, in turn, influence the operation and performance of the systems.

Hot water consumption patterns. Two hot water consumption patterns were determined for Australian households. These consumption patterns were based on the upper and lower daily hot water demand described by the Plumbing Reference Guide of Australia [12], i.e. 50 and 70 litres per person per day (L/p/day) and the average Australian household size (2-3 people/household [13]). Then, considering the lower and upper values reported for both variables, it was determined a minimum and a maximum daily hot water consumption pattern for Australian households equal to 100 and 210 $\mathrm{L} / \mathrm{hh} /$ day, respectively. This water consumption pattern is comparable to empirical water consumption measurements of hot water end use points (showers, baths and taps) in households in Brisbane, i.e. $186 \mathrm{~L} / \mathrm{hh} / \mathrm{d}$ [7].

Hourly hot water consumption patterns were derived from the minimum and maximum daily water consumption patterns by considering a morning water consumption period from $7 \mathrm{AM}$ to $9 \mathrm{AM}$, followed by an afternoon-evening consumption period from $1 \mathrm{PM}$ to $9 \mathrm{PM}$. A peaking factor equal to 2 was considered for the evening period between $5 \mathrm{PM}$ and $8 \mathrm{PM}$, while a peaking factor of 1 was considered for the other hours with hot water consumption events. Figure 2 illustrates the estimated hot water consumption patterns.

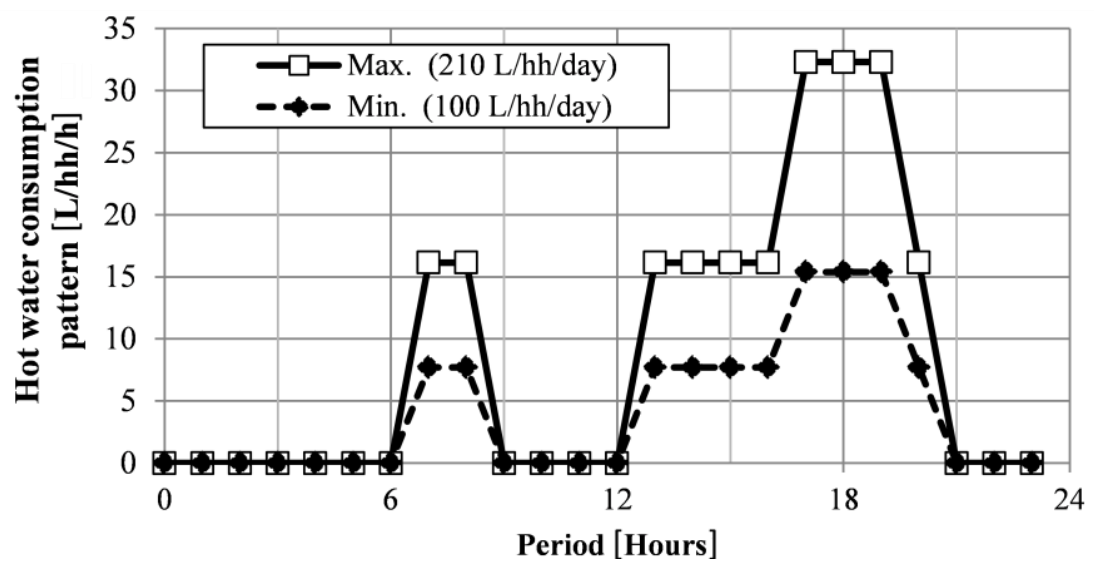

Figure 2. Estimated hot water consumption patterns

Hot water tank capacity. Two hot water tank capacities were simulated (i.e. 160 and $330 \mathrm{~L}$ ). These capacities were determined based on typical hot water tank sizes retailed in Australia. 
Technical specifications of DWH. The electric and thermic specifications of each studied domestic water heater type (i.e. electric, solar and heat pump) are presented in Table 1. The specifications for solar collectors are presented in Table 2.

Table 1. Electric and thermic specifications of DWH

\begin{tabular}{cccc}
\hline Parameters & Electric & Solar & Heat pump \\
\hline Electric power [kW] & 3.6 & 1.8 & 1.3 \\
Standby power [W] & 10 & 10 & 10 \\
Rated coefficient of performance [W/W] & 1 & - & 3.2 \\
Heat losses in tanks [W/K] & 1 & 1 & 1 \\
Heat losses in pipes [W/K] & 0 & 0 & 0 \\
\hline
\end{tabular}

Table 2. Technical specification of the solar collectors

\begin{tabular}{cc}
\hline Parameter & Value \\
\hline Number of collectors & 2 \\
Gross area [m²/collector] & 1.983 \\
Test fluid & Water \\
Test flow rate $[\mathrm{L} / \mathrm{s}]$ & 0.037 \\
Test correlation type & Inlet \\
Optical coefficient (dimensionless) & 0.608 \\
Linear loss coefficient $\left[\mathrm{W} / \mathrm{m}^{2} \mathrm{~K}\right]$ & -5.4707 \\
Quadratic loss coefficient $\left[\mathrm{W} / \mathrm{m}^{2} \mathrm{~K}^{2}\right]$ & -0.0271 \\
Linear angle modifier coefficient & -0.1718 \\
Quadratic angle modifier coefficient & -0.058 \\
\hline
\end{tabular}

The rated Coefficient of Performance (COP) of the analysed heat pump system, 3.2 (Table 1), is only achieved at rated conditions, including: rated evaporator inlet air dry-bulb temperature of $19.7{ }^{\circ} \mathrm{C}$, rated evaporator inlet air wet-bulb temperature of 13.5 ${ }^{\circ} \mathrm{C}$, and rated condenser inlet water temperature of $57.5^{\circ} \mathrm{C}$. Under variable operational conditions (i.e. site specific conditions across the different cities and water consumption patterns analysed), the $C O P$ of heat pumps will also vary giving rise to different energy consumption patterns (e.g. colder weather conditions promote a reduction in the COP and an increase in the energy consumption of heat pumps).

The operational thermal efficiency of solar collectors was calculated in EnergyPlus 8.1 using the following equation:

$$
\eta=c_{0}+c_{1} \frac{\left(T_{i n}-T_{a i r}\right)}{I}+c_{2} \frac{\left(T_{i n}-T_{\text {air }}\right)^{2}}{I}
$$

where:

- $\quad \eta$ is thermal efficiency of the collector;

- $c_{0}$ is optical coefficient (dimensionless);

- $c_{1}$ is the linear loss coefficient $\left[\mathrm{W} / \mathrm{m}^{2} \mathrm{~K}\right]$;

- $c_{2}$ is the quadratic loss coefficient $\left[\mathrm{W} / \mathrm{m}^{2} \mathrm{~K}^{2}\right]$;

- $T_{i n}$ is the temperature of the collector $[\mathrm{K}]$;

- $T_{\text {air }}$ is the temperature of the air $[\mathrm{K}]$;

- $I$ is the solar radiation $\left[\mathrm{W} / \mathrm{m}^{2}\right]$. 
Eq. (1) calculates the thermal efficiency of collectors as a function of the useful heat gain of collectors divided by the total incident solar radiation. The useful heat gain is the heat collected after heat losses related to convection, radiance and conduction heat transfer phenomena. These phenomena are usually represented by empirically determined correction factors, which can be used in quadratic correlation equations to determine the thermal efficiency of collectors. The coefficients $c_{1}$ and $c_{2}$ in Table 2 indicate that the thermal efficiency of the studied collector is represented by a parabola that opens downwards. This leads to a reduction of the thermal efficiency with an increase in the temperature gradient or a decrease in the solar radiation.

In the simulations, incident angle modifiers were also considered so as to calculate the variation of the transmittance of collector glazing with the incident angle of radiation. This variation was calculated in EnergyPlus 8.1 using the following quadratic equation:

$$
K_{\tau \alpha}=1+b_{0}\left(\frac{1}{\cos \theta}-1\right)+b_{1}\left(\frac{1}{\cos \theta}-1\right)^{2}
$$

where:

- $K_{\tau \alpha}$ is the angle modifier;

- $b_{0}$ is the linear angle modifier coefficient;

- $b_{1}$ is the quadratic angle modifier coefficient;

- $\theta$ is the radiance incident angle.

Negative angle modifier coefficients (Coefficients 2 and 3 of incident angle modifiers in Table 2) indicate that the transmittance of collector glazing decrease with an increase of the radiance incident angle.

\section{Performance analyses}

The performance of DWH was assessed considering their energy performance (i.e. energy intensity and power peaks), as well as their level of service (i.e. compliance rate with minimum temperature thresholds).

Energy intensity. The energy intensity (i.e. unit of energy per unit of water) is an indicative of the level of energy efficiency of a system, as it represents how much energy is embodied in a certain volume of water. The energy intensity of the assessed systems was measured using eq. (3):

$$
E I=\frac{E_{A}}{W_{A}}
$$

where:

- $E I$ is the energy intensity of the DWH $\left[\mathrm{kWh} / \mathrm{m}^{3}\right]$;

- $E_{A}$ is the annual energy consumption of the DWH $[\mathrm{kWh}]$;

- $W_{A}$ is the annual hot water consumption of the DWH $\left[\mathrm{m}^{3}\right]$.

Power peak. The power peak is the energy consumed during peak hours for the electricity grid. Although peak hours may vary considerably depending on the season and location, it usually encompasses the period within 4 PM and 8 PM as per a desktop review made for 14 different electricity distributors in Australia. Therefore, the power peak of DWH was determined as the proportion between the electricity consumed within $4 \mathrm{PM}$ and $8 \mathrm{PM}$ in relation to the total daily consumption throughout the year. 
Compliance rate with minimum temperature thresholds. The compliance with the minimum temperature set-points for water end uses $\left(40^{\circ} \mathrm{C}\right)$ and hot water tanks $\left(60^{\circ} \mathrm{C}\right)$ was estimated in order to determine the level of service of DWH. The first threshold determines the level of comfort provided to users; whereas, the second, the level of protection against Legionnaire's diseases [14]. The compliance rate for both temperature thresholds was calculated as the proportion of the number of hours in which the temperature was equal or over the minimum thresholds to the total number of hours throughout the year.

\section{RESULTS AND DISCUSSION}

\section{Energy intensity of DWH}

The energy intensity variation among the different DWH scenarios is shown in Table 3. Electric and heat pump were predicted to be the most and the least energy intensive water heating systems, respectively. The energy intensity of electric ranged from 25.6 to $39 \mathrm{kWh} / \mathrm{m}^{3}$. On the other hand, solar and heat pump systems achieved much lower energy intensities, varying from 12.2 to $29.2 \mathrm{kWh} / \mathrm{m}^{3}$ for solar systems and from 11.1 to $18.6 \mathrm{kWh} / \mathrm{m}^{3}$ for heat pump systems. Climatic conditions also played a significant role on the energy demand of water heating systems, for which systems located in Brisbane (i.e. sub-tropical climate) had a considerably lower energy intensity than systems in Sydney and Melbourne (i.e. temperate climates). Vieira et al. [9] also found similar results for heat pumps under different climates across Australia.

Table 3. Energy intensity of DWH $\left(\mathrm{kWh} / \mathrm{m}^{3}\right)$

\begin{tabular}{|c|c|c|c|c|c|c|c|c|}
\hline \multirow{2}{*}{\multicolumn{3}{|c|}{$\begin{array}{c}\text { City: } \\
\text { Water consumption pattern: }\end{array}$}} & \multicolumn{2}{|c|}{ Sydney } & \multicolumn{2}{|c|}{ Melbourne } & \multicolumn{2}{|c|}{ Brisbane } \\
\hline & & & \multirow[t]{2}{*}{ Low } & \multirow[t]{2}{*}{ High } & \multirow[t]{2}{*}{ Low } & \multirow[t]{2}{*}{ High } & \multirow[t]{2}{*}{ Low } & \multirow[t]{2}{*}{ High } \\
\hline Type & Capacity & Tariff & & & & & & \\
\hline \multirow{6}{*}{$\frac{\stackrel{U}{U}}{\frac{\mathscr{U}}{\Delta}}$} & \multirow{3}{*}{$160 \mathrm{~L}$} & All day & 34.1 & 28.0 & 39.2 & 32.6 & 31.9 & 26.0 \\
\hline & & Controlled & 34.2 & 28.1 & 39.3 & 32.6 & 32.1 & 26.1 \\
\hline & & Night off-peak & 34.0 & 27.5 & 38.9 & 31.8 & 31.9 & 25.6 \\
\hline & \multirow{3}{*}{$330 \mathrm{~L}$} & All day & 34.0 & 28.0 & 39.3 & 32.6 & 31.8 & 26.1 \\
\hline & & Controlled & 34.0 & 28.2 & 39.2 & 32.7 & 31.9 & 26.2 \\
\hline & & Night off-peak & 33.7 & 28.1 & 38.9 & 32.6 & 31.5 & 26.1 \\
\hline \multirow{6}{*}{ 흉 } & \multirow{3}{*}{$160 \mathrm{~L}$} & All day & 19.6 & 19.8 & 29.2 & 26.2 & 15.7 & 17.6 \\
\hline & & Controlled & 19.7 & 20.0 & 29.2 & 27.0 & 15.9 & 17.2 \\
\hline & & Night off-peak & 19.0 & 19.5 & 28.4 & 26.2 & 15.0 & 16.7 \\
\hline & \multirow{3}{*}{$330 \mathrm{~L}$} & All day & 17.3 & 19.5 & 28.0 & 27.3 & 13.3 & 16.5 \\
\hline & & Controlled & 16.9 & 19.4 & 28.0 & 27.1 & 13.2 & 16.4 \\
\hline & & Night off-peak & 15.9 & 19.0 & 27.3 & 26.7 & 12.2 & 16.1 \\
\hline \multirow{6}{*}{ 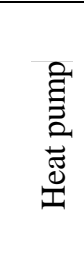 } & \multirow{3}{*}{$160 \mathrm{~L}$} & All day & 15.5 & 12.1 & 18.3 & 14.3 & 14.3 & 11.1 \\
\hline & & Controlled & 18.5 & 12.2 & 18.6 & 15.1 & 17.3 & 11.5 \\
\hline & & Night off-peak & 18.4 & 12.4 & 18.1 & 12.2 & 16.8 & 11.3 \\
\hline & \multirow{3}{*}{$330 \mathrm{~L}$} & All day & 15.6 & 12.3 & 18.1 & 14.5 & 14.6 & 11.4 \\
\hline & & Controlled & 14.3 & 12.4 & 16.2 & 14.6 & 13.4 & 11.5 \\
\hline & & Night off-peak & 15.4 & 12.3 & 17.1 & 13.0 & 14.4 & 11.3 \\
\hline
\end{tabular}

The hot water tank capacity had a varying effect on the energy intensity of DWHs. For heat pump systems under the controlled and night electricity supply tariffs, the energy intensity was inversely proportional to the hot water tank size, in which an increase of the tank size from 160 to $330 \mathrm{~L}$ promoted a decrease of the overall energy intensity by around $3.1 \%\left(0.7 \mathrm{kWh} / \mathrm{m}^{3}\right)$. Considering the use of solar DWHs to meet the 
low hot water consumption pattern (i.e. $100 \mathrm{~L} / \mathrm{hh} /$ day), a significant reduction in the energy intensity was achieved by using hot water tanks with $330 \mathrm{~L}$ capacity as opposed to $160 \mathrm{~L}$ tanks, i.e. around $10.3 \%\left(2.2 \mathrm{kWh} / \mathrm{m}^{3}\right)$. However, under the high water consumption pattern, the hot water tank capacity had a minor influence on the performance of solar DWHs, i.e. $1.9 \%\left(0.4 \mathrm{kWh} / \mathrm{m}^{3}\right)$. The energy intensity of electric DWHs was not considerably influenced by changes in the energy intensity between the two storage tank sizes.

The energy intensity of electric and heat pump DWHs decreased with an increase of the hot water consumption pattern from 100 to $210 \mathrm{~L} / \mathrm{hh} /$ day. Likewise, the energy intensity of solar DWH in Melbourne also decreased for the high hot water consumption pattern. In contrast, the opposite can be stated for the solar DWHs in Brisbane and Sydney, where the high water consumption pattern gave rise to greater energy intensities (Table 3).

\section{Power peak consumption}

The power peak consumption (i.e. electricity consumption within 4 PM and 8 PM) was totally mitigated by interrupting the electricity supply during peak hours for the electricity grid through the use of controlled and night off-peak electricity supply tariffs. On the other hand, the power peak consumption for systems under the all day electricity supply tariff ranged from 18 to $68 \%$ (Table 4 ).

Table 4. Power peak consumption of DWH (\%)

\begin{tabular}{|c|c|c|c|c|c|c|c|c|}
\hline \multirow{2}{*}{\multicolumn{3}{|c|}{$\begin{array}{c}\text { City: } \\
\text { Water consumption pattern: }\end{array}$}} & \multicolumn{2}{|c|}{ Sydney } & \multicolumn{2}{|c|}{ Melbourne } & \multicolumn{2}{|c|}{ Brisbane } \\
\hline & & & \multirow{2}{*}{$\begin{array}{c}\text { Low } \\
-\end{array}$} & \multirow{2}{*}{$\frac{\text { High }}{-}$} & \multirow{2}{*}{$\frac{\text { Low }}{-}$} & \multirow{2}{*}{$\begin{array}{c}\text { High } \\
-\end{array}$} & \multirow{2}{*}{$\frac{\text { Low }}{-}$} & \multirow{2}{*}{$\frac{\text { High }}{-}$} \\
\hline Type & Capacity & Tariff & & & & & & \\
\hline \multirow{6}{*}{ 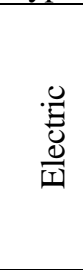 } & \multirow{3}{*}{$160 \mathrm{~L}$} & All day & 41 & 45 & 34 & 48 & 43 & 42 \\
\hline & & Controlled & 0 & 0 & 0 & 0 & 0 & 0 \\
\hline & & Night off-peak & 0 & 0 & 0 & 0 & 0 & 0 \\
\hline & \multirow{3}{*}{$330 \mathrm{~L}$} & All day & 32 & 58 & 23 & 50 & 36 & 51 \\
\hline & & Controlled & 0 & 0 & 0 & 0 & 0 & 0 \\
\hline & & Night off-peak & 0 & 0 & 0 & 0 & 0 & 0 \\
\hline \multirow{6}{*}{$\begin{array}{l}\frac{\tilde{t}}{0} \\
\stackrel{0}{2}\end{array}$} & \multirow{3}{*}{$160 \mathrm{~L}$} & All day & 39 & 50 & 40 & 51 & 39 & 48 \\
\hline & & Controlled & 0 & 0 & 0 & 0 & 0 & 0 \\
\hline & & Night off-peak & 0 & 0 & 0 & 0 & 0 & 0 \\
\hline & \multirow{3}{*}{$330 \mathrm{~L}$} & All day & 24 & 39 & 18 & 53 & 24 & 30 \\
\hline & & Controlled & 0 & 0 & 0 & 0 & 0 & 0 \\
\hline & & Night off-peak & 0 & 0 & 0 & 0 & 0 & 0 \\
\hline \multirow{6}{*}{ 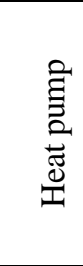 } & \multirow{3}{*}{$160 \mathrm{~L}$} & All day & 42 & 42 & 45 & 47 & 37 & 45 \\
\hline & & Controlled & 0 & 0 & 0 & 0 & 0 & 0 \\
\hline & & Night off-peak & 0 & 0 & 0 & 0 & 0 & 0 \\
\hline & \multirow{3}{*}{$330 \mathrm{~L}$} & All day & 33 & 68 & 35 & 57 & 27 & 58 \\
\hline & & Controlled & 0 & 0 & 0 & 0 & 0 & 0 \\
\hline & & Night off-peak & 0 & 0 & 0 & 0 & 0 & 0 \\
\hline
\end{tabular}

Across all cities, the power peak consumption of the heat pump systems was shown to decrease by an average of $13 \%$ with the adoption of $330 \mathrm{~L}$ tanks as opposed to $160 \mathrm{~L}$ tanks. Under the low water consumption pattern $(100 \mathrm{~L} / \mathrm{hh} /$ day $)$, the power peak of electric and solar systems was reduced by $9 \%$ when using the larger hot water tank size. In contrast, under the high water consumption pattern $(210 \mathrm{~L} / \mathrm{hh} /$ day $)$, these systems underwent an increase of $12 \%$ on average of their power peak consumption when using 330 L tanks. 


\section{Compliance rates with temperature thresholds}

The compliance with the minimum temperature set-point for water end uses $\left(40{ }^{\circ} \mathrm{C}\right)$ and hot water tanks $\left(60{ }^{\circ} \mathrm{C}\right)$ for each scenario is presented in Table 5 and Table 6 , respectively. On average, under all electricity supply tariff options for both performance criteria, the solar systems recorded the highest compliance rates, followed by electric systems and heat pump systems.

In considering the end use temperature, the Brisbane scenarios presented the highest compliance rates, followed by Sydney and Melbourne. For all DWHs operating under the all day and controlled electricity supply tariffs, the compliance rates were above $98 \%$. On the other hand, the DWHs had a failure rate of up to 54\% under the night off-peak tariff. As described by Vieira et al. [7], the use of night off-peak tariffs may be associated with a considerable reduction in the level of service of water heating systems.

The level of compliance with the hot water end use temperature threshold was enhanced by $4 \%$ on average when using either the low water consumption pattern or the larger hot water tank size. Therefore, the selection of small tank sizes is likely to have a minor impact on the hot water supply comfort for households. Nonetheless, caution has to be practiced in order to guarantee acceptable levels of compliance with the minimum temperature threshold $\left(60^{\circ} \mathrm{C}\right)$ to prevent Legionnaire's disease.

Table 5. End use temperature compliance rate (\%)

\begin{tabular}{|c|c|c|c|c|c|c|c|c|}
\hline \multirow{2}{*}{\multicolumn{3}{|c|}{$\begin{array}{c}\text { City: } \\
\text { Water consumption pattern: }\end{array}$}} & \multicolumn{2}{|c|}{ Sydney } & \multicolumn{2}{|c|}{ Melbourne } & \multicolumn{2}{|c|}{ Brisbane } \\
\hline & & & \multirow{2}{*}{$\begin{array}{c}\text { Low } \\
- \\
\end{array}$} & \multirow{2}{*}{$\frac{\text { High }}{-}$} & \multirow{2}{*}{$\begin{array}{c}\text { Low } \\
- \\
\end{array}$} & \multirow{2}{*}{$\begin{array}{c}\text { High } \\
- \\
\end{array}$} & \multirow{2}{*}{$\begin{array}{c}\text { Low } \\
- \\
\end{array}$} & \multirow{2}{*}{ High } \\
\hline Type & Capacity & Tariff & & & & & & \\
\hline \multirow{6}{*}{$\frac{\stackrel{U}{\Xi}}{\frac{d}{U}}$} & \multirow{3}{*}{$160 \mathrm{~L}$} & All day & 100 & 100 & 100 & 100 & 100 & 100 \\
\hline & & Controlled & 100 & 100 & 100 & 100 & 100 & 100 \\
\hline & & Night off-peak & 100 & 97 & 100 & 92 & 100 & 99 \\
\hline & \multirow{3}{*}{$330 \mathrm{~L}$} & All day & 100 & 100 & 100 & 100 & 100 & 100 \\
\hline & & Controlled & 100 & 100 & 100 & 100 & 100 & 100 \\
\hline & & Night off-peak & 100 & 100 & 100 & 100 & 100 & 100 \\
\hline \multirow{6}{*}{$\begin{array}{l}\text { 营 } \\
\text { ஸ }\end{array}$} & \multirow{3}{*}{$160 \mathrm{~L}$} & All day & 100 & 100 & 100 & 100 & 100 & 100 \\
\hline & & Controlled & 100 & 100 & 100 & 100 & 100 & 100 \\
\hline & & Night off-peak & 100 & 99 & 100 & 94 & 100 & 100 \\
\hline & \multirow{3}{*}{$330 \mathrm{~L}$} & All day & 100 & 100 & 100 & 100 & 100 & 100 \\
\hline & & Controlled & 100 & 100 & 100 & 100 & 100 & 100 \\
\hline & & Night off-peak & 100 & 100 & 100 & 100 & 100 & 100 \\
\hline \multirow{6}{*}{ 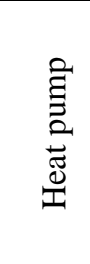 } & \multirow{3}{*}{$160 \mathrm{~L}$} & All day & 100 & 100 & 100 & 99 & 100 & 100 \\
\hline & & Controlled & 100 & 100 & 100 & 98 & 100 & 100 \\
\hline & & Night off-peak & 96 & 93 & 87 & 75 & 96 & 93 \\
\hline & \multirow{3}{*}{$330 \mathrm{~L}$} & All day & 100 & 100 & 100 & 100 & 100 & 100 \\
\hline & & Controlled & 100 & 100 & 100 & 100 & 100 & 100 \\
\hline & & Night off-peak & 98 & 97 & 93 & 86 & 98 & 97 \\
\hline
\end{tabular}

Taking into account the minimal hot water tank temperature $\left(60^{\circ} \mathrm{C}\right)$ compliance rate, Brisbane and Sydney displayed similar results across the scope of the simulations, whereas Melbourne displayed a much lower compliance rate, as shown by the data in Table 6. This can be attributed to the difference in climatic conditions between the three cities, whereby Brisbane, Sydney and Melbourne have annual average air temperatures of $19.9,18.4$ and $15.0{ }^{\circ} \mathrm{C}$, respectively.

Solar systems were the most resilient systems against Legionella spp. as a result of their higher average compliance level with the minimal hot water tank temperature 
(93\%), followed by electric systems (90\%), and finally heat pump systems (86\%). The compliance rates of DWHs operating under the all day, controlled and night electricity supply tariffs ranged between 93 and 100\%, 81 and 99\%, and 46 and 95\%, respectively (Table 6). Systems operating under the night tariff showed the most variable level of compliance due to the limited availability of energy under this tariff option.

The compliance with the minimum temperature threshold for hot water tanks was $4 \%$ greater for systems with $330 \mathrm{~L}$ hot water tanks in comparison to systems with $160 \mathrm{~L}$ tanks. This is due to the increased capacity of $330 \mathrm{~L}$ tanks to prevent excessive temperature drops, particularly under high water consumption patterns or night electricity supply tariff.

Table 6. Hot water tank compliance rate with the minimum temperature threshold (\%)

\begin{tabular}{|c|c|c|c|c|c|c|c|c|}
\hline \multirow{2}{*}{\multicolumn{3}{|c|}{$\begin{array}{c}\text { City: } \\
\text { Water consumption pattern: }\end{array}$}} & \multicolumn{2}{|c|}{ Sydney } & \multicolumn{2}{|c|}{ Melbourne } & \multicolumn{2}{|c|}{ Brisbane } \\
\hline & & & \multirow{2}{*}{$\frac{\text { Low }}{-}$} & \multirow{2}{*}{$\frac{\text { High }}{-}$} & \multirow{2}{*}{$\frac{\text { Low }}{-}$} & \multirow{2}{*}{$\begin{array}{c}\text { High } \\
-\end{array}$} & \multirow{2}{*}{$\frac{\text { Low }}{-}$} & \multirow{2}{*}{$\begin{array}{c}\text { High } \\
- \\
\end{array}$} \\
\hline Type & Capacity & Tariff & & & & & & \\
\hline \multirow{6}{*}{$\frac{\mathscr{U}}{\stackrel{\Xi}{U}}$} & \multirow{3}{*}{$160 \mathrm{~L}$} & All day & 100 & 100 & 100 & 100 & 100 & 100 \\
\hline & & Controlled & 88 & 92 & 91 & 88 & 90 & 94 \\
\hline & & Night off-peak & 81 & 65 & 76 & 61 & 83 & 66 \\
\hline & \multirow{3}{*}{$330 \mathrm{~L}$} & All day & 100 & 100 & 100 & 100 & 100 & 100 \\
\hline & & Controlled & 96 & 92 & 98 & 87 & 96 & 95 \\
\hline & & Night off-peak & 79 & 84 & 81 & 79 & 80 & 86 \\
\hline \multirow{6}{*}{$\frac{\bar{\Xi}}{0}$} & \multirow{3}{*}{$160 \mathrm{~L}$} & All day & 100 & 100 & 100 & 100 & 100 & 100 \\
\hline & & Controlled & 95 & 91 & 91 & 88 & 97 & 92 \\
\hline & & Night off-peak & 90 & 77 & 82 & 66 & 92 & 81 \\
\hline & \multirow{3}{*}{$330 \mathrm{~L}$} & All day & 100 & 100 & 100 & 100 & 100 & 100 \\
\hline & & Controlled & 99 & 95 & 89 & 95 & 99 & 97 \\
\hline & & Night off-peak & 92 & 88 & 91 & 80 & 95 & 90 \\
\hline \multirow{6}{*}{ 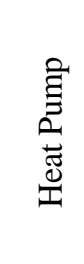 } & \multirow{3}{*}{$160 \mathrm{~L}$} & All day & 99 & 100 & 93 & 93 & 99 & 99 \\
\hline & & Controlled & 89 & 92 & 85 & 81 & 89 & 92 \\
\hline & & Night off-peak & 78 & 62 & 61 & 46 & 78 & 62 \\
\hline & \multirow{3}{*}{$330 \mathrm{~L}$} & All day & 100 & 100 & 98 & 95 & 100 & 99 \\
\hline & & Controlled & 96 & 93 & 95 & 82 & 96 & 94 \\
\hline & & Night off-peak & 78 & 80 & 61 & 61 & 78 & 80 \\
\hline
\end{tabular}

\section{CONCLUSIONS AND RECOMMENDATIONS}

The objective of this paper was to analyse the performance of Domestic Water Heaters (DWHs) in the three largest cities of Australia by using a holistic approach based on energy and level of service indicators. The operation of water heaters was simulated using computational models, providing a valuable source of data due to the lack of empirical works in this area. The following conclusions and recommendations were drawn from the present study:

- The energy intensity typically decreases with the adoption of heat pumps, followed by solar systems, which is consistent with other similar research;

- The energy intensity tend to reduce with the adoption of larger hot water tank sizes for heat pump and solar DWHs;

- More efficient DWH may need to be used to enhance the energy performance of systems installed in colder regions (e.g. Melbourne) due to heat losses and lower performance of solar and heat pump systems, including but not limited to: solar DWH with more efficient collectors and larger collector areas and heat pumps with a greater Coefficient of Performance $(C O P)$; 
- The energy efficiency of DWH under low hot water consumption patterns may be improved by reducing heat losses in hot water tanks, particularly in colder weather conditions;

- Power peaks can be totally diverted from peak hours by using controlled and off-peak electricity supply tariffs without a significant reduction in the level of service of water heating systems;

- Night off-peak electricity supply tariffs may reduce the level of compliance with the minimum hot water temperature thresholds, particularly when using heat pump DWH and small hot water tank sizes in cold weather conditions;

- Optimal energy efficiency performance at adequate levels of compliance with minimum temperature thresholds could be achieved predominantly by heat pumps with the larger tank size (330 L) connected to the controlled electricity supply tariff (18 hours electricity supply during off-peak hours).

Results demonstrate the need for a more holistic approach for the design and assessment of domestic water heaters taking into account not only the technology type to heat water (e.g. solar, heat pump or electric), but also site specific characteristics (e.g. electricity tariff and water consumption patterns). The herein conclusions and recommendations may be used to assist in underpinning energy and water efficiency building code requirements and other sustainable development policies in Australia that relate to residential heating systems. Nonetheless, caution has to be practiced, as site specific conditions may promote a considerable variation in the performance of DWH. In order to strengthen the knowledge of DWH performance in Australia, further studies are required in order to address the performance of other DWH types (e.g. solar and heat pump DWHs with high energy efficiency) and different weather conditions throughout Australia (e.g. Darwin, Hobart, Perth).

\section{REFERENCES}

1. Garmston, H. and Pan, W., Non-compliance with Building Energy Regulations: The Profile, Issues, and Implications on Practice and Policy in England and Wales, Journal of Sustainable Development of Energy, Water and Environment Systems, Vol. 1, No. 4, pp 340-352, 2013, http://dx.doi.org/10.13044/j.sdewes.2013.01.0026

2. Pérez-Lombard, L., Ortiz, J. and Pout, C., A Review on Buildings Energy Consumption Information, Energy and Buildings, Vol. 40, No. 3, pp 394-398, 2008, http://dx.doi.org/10.1016/j.enbuild.2007.03.007

3. Ghisi, E., Gosch, S. and Lamberts, R., Electricity End-uses in the Residential Sector of Brazil, Energy Policy, Vol. 35, No. 8, pp 4107-4120, 2007, http://dx.doi.org/10.1016/j.enpol.2007.02.020

4. Arpke, A. and Hutzler, N., Domestic Water use in the Unitede States: A Life-cycle Approach, Journal of Industrial Ecology, Vol. 10, No. 1-2, pp 169-184, 2006, http://dx.doi.org/10.1162/108819806775545312

5. Lee, M. and Tansel, B., Life Cycle Based Analysis of Demands and Emissions for Residential Water-using Appliances, Journal of Environmental Management, Vol. 101, pp 75-81, 2012, http://dx.doi.org/10.1016/j.jenvman.2012.02.010

6. Beal, C. D., Stewart, R. A. and Bertone, E., Evaluating the Energy and Carbon Reduction Resulting from Resource-efficient Household Stock, Energy and Buildings, Vol. 55, pp 422-432, 2012, http://dx.doi.org/10.1016/j.enbuild.2012.08.004

7. Vieira, A. S., Beal, C. D. and Stewart, R. A., Residential Water Heaters in Brisbane, Australia: Thinking Beyond Technology Selection to Enhance Energy Efficiency and Level of Service, Energy and Buildings, Vol. 82, pp 222-236, 2014, http://dx.doi.org/10.1016/j.enbuild.2014.07.007 
8. QLD, Delivering Affordable, Safe and Reliable Energy and Water for Queensland, Queensland Government, 2012, http://statements.qld.gov.au/Statement/Id/80510, [Accessed: 15-May-2014]

9. Vieira, A. S., Stewart, R. A. and Beal, C. D., Air Source Heat Pump Water Heater in Residential Buildings in Australia: Identification of Key Performance Parameters, Energy and Buildings, Vol. 91, pp 148-162, 2015, http://dx.doi.org/10.1016/j.enbuild.2015.01.041

10. Hendron, R., Anderson, R., Christensen, C., Eastment, M. and Reeves, P., Development of an Energy Savings Benchmark for All Residential End-Uses, Proceedings of SIMBUILD2004 Conference, Colorado, August 4-6, 2004, pp 1-11.

11. Kenway, S., The Water-energy Nexus and Urban Metabolism - Connections in Cities, Urban Water Security Research Alliance Technical Report 100, 2013.

12. Australia, Plumber Reference Guide - Solar \& Heat Pump Hot Water Systems, Vol. 6. Department of Climate Change and Energy Efficiency - Commonwealth of Australia, 2010, p 150.

13. ABS, Year Book Australia, 2009-2010: Households and Families, Australian Bureau of

http://www.abs.gov.au/AUSSTATS/abs@.nsf/lookup/916F96F929978825CA257737 00169C65?opendocument, [Accessed: 10-May-2014].

14. Serrano-Suárez, A., Dellundé, J., Salvadó, H., Cervero-Aragó, S., Méndez, J., Canals, O., Blanco, S., Arcas, A. and Araujo, R., Microbial and Physicochemical Parameters associated with Legionella Contamination in Hot Water Recirculation Systems, Environmental Science and Pollution Research International, Vol. 20, No. 8, pp 5534-44, 2013, http://dx.doi.org/10.1007/s11356-013-1557-5 